\title{
Short Communication: Detection of bioactive compounds in essential oil from lemongrass cultivated in Ngantang, Malang, East Java, Indonesia
}

\author{
ENDANG SRI HARTATIE ${ }^{1, \bullet}$, INDAH PRIHARTINI ${ }^{2}$, WAHYU WIDODO ${ }^{2}$, AHMAD WAHYUDI ${ }^{2}$ \\ ${ }^{1}$ Doctoral Program of Agricultural Science, Universitas Muhammadiyah Malang. Jl. Raya Tlogomas 246, Malang 65144, East Java, Indonesia. \\ Tel.: +62-341-464318,464319,460948, Fax.: +62-341-460782, •email: endang_s@umm.ac.id \\ ${ }^{2}$ Department of Agriculture Science, Universitas Muhammadiyah Malang. Jl. Raya Tlogomas 246, Malang 65144, East Java, Indonesia.
}

Manuscript received: 5 April 2020. Revision accepted: 28 May 2020.

\begin{abstract}
Hartatie ES, Prihartini I, Widodo W, Wahyudi A. 2020. Short Communication: Detection of bioactive compounds in essential oil from lemongrass cultivated in Ngantang, Malang, East Java, Indonesia. Biodiversitas 21: 2822-2826. Lemongrass (Cymbopogon citratus) commonly known as West Indian lemongrass is a member of the Poaceae family and belongs to genus Cymbopogon. It is one of the plants commonly used in fresh form as a spice by the people in Indonesia and widely planted in the yard of the house. Lemongrass contains several bioactive compounds and it might be extracted to obtain essential oils useful for many applications such as flavor and fragrance ingredients, perfumery, cosmetics, food preservation, pharmaceutical. The chemical composition of essentials oil can be variable, according to the genetic diversity, habitat, weather, and cultural treatment. The aim of study was to investigate the bioactive compounds in essential oil from lemongrass stalk and lemongrass leaves which cultivated in Ngantang, Malang, East Java, Indonesia. Detection of bioactive compounds was carried out by gas chromatography-mass spectrometry (GC-MS). The results of study are the main compound in lemongrass essential oil was citral. There is a difference between the citral content of essential oils from lemongrass stalk compared to essential oils from lemongrass leaves, both in quantity and components. The citral (geranial and neral) content of essential oil made from stalk was higher than made from leaves, but the amount of bioactive compounds of essential oils from leaves more than from the stalk.
\end{abstract}

Keywords: Bioactive compound, GC-MS, lemongrass essential oil, Ngantang area

\section{INTRODUCTION}

The Cymbopogon genus is comprised of about 55 species, indigenous to tropical and semi-tropical areas of Asia and cultivated in South and Central America, and other tropical countries (Abdulazeez et al. 2016) Two main species, Cymbopogon flexuosus and Cymbopogon citratus. vastly cultivated in different regions of the world due to the high citral content in their essential oil (Haque et al. 2018). C. citratus, popularly known as lemongrass. It is an aromatic perennial plant of the Poaceae family, with long slender green leaves, widely distributed and extensively used worldwide. It is widely used as an herb in Asian cuisine, has a citrus flavor and can be dried and powdered, or used fresh. It is commonly used in teas, soups, and curries; also are suitable for poultry, fish, beef, and seafood.

Lemongrass can be extracted into essential oils. Traditionally, steam and hydrodistillation techniques are generally used to extract the essential oils from lemongrass leaves (Yen and Lin 2017). The lemongrass essential oil quality is measured by citral content because it is the major active compound found in lemongrass. Citral is comprised of two stereo-isomeric monoterpene aldehydes are geranial (trans-citral) and neral (cis-citral). Generally, lemongrass oil contains greater than $45 \%$ of citral, but the amount can vary widely among species. C. citratus commonly possesses around 30-94\% of citral with geranial predominance. The common name of some species and their applications are documented by (Avoseh et al. 2015). C. citratus is ranked as one of the most widely distributed of the Cymbopogon genus which is used in every part of the world. Common names of $C$. citratus are lemongrass (India, Nigeria), limonaria (Argentina, Columbia), cana canta (Cuba), grass tea (Costa Rica), capim-santo (Brazil), fever grass (Trinidad and Tobago). Different chemotypes of Cympobopon species contain varying major compounds.

The majority of the $C$. citratus analysis a remarkably high percentage of neral and geranial. Geranial $\left(\mathrm{C}_{10} \mathrm{H}_{16} \mathrm{O}\right)$ and neral $\left(\mathrm{C}_{10} \mathrm{H}_{16} \mathrm{O}\right)$ contents of $C$. citratus from Angola are $40.55 \%$ and $28.26 \%$, respectively) (Soares et al. 2013. In addition, geranial and neral contents of C. citratus essential oil from Iran are $39.16 \%$ and $30.95 \%$, respectively (Avoseh et al. 2015). Geranial and neral contents of C. citratus essential oil from Mali are 45.3-56.2 $\%$ and $21.3-32.5 \%$, respectively, while Geranial and neral contents of $C$. citratus essential oil from Ivory Coast are 30.5-34.5-34.0\% and 23.3-26.3\%, respectively (Sidibé et al. 2011). Lemongrass contains approximately $1-2 \%$ of essential oils in dry mass and has a wide variation in chemical composition as a function of genetic diversity, habitat, weather, cultural treatment, harvesting age, extraction techniques and parts of lemongrass (Mirghani et al. 2012; Putra et al. 2012; Abdulazeez et al. 2016; Yen and 
Lin 2017).

In Indonesia, C. citratus, which is more popularly known as serai dapur, is commonly found in the backyard. This plant is planted to be used as cooking spices and usually, only stems are used. therefore it needs to be studied more deeply and publicized so as to improve the function and economic value of this plant. The purpose of this research is to detect the chemical quality of essential oil from lemongrass cultivated in Ngantang, Malang, Indonesia which can be used as a basis for the application of essential oil products as food additives, especially as preservatives for meat products.

\section{MATERIALS AND METHODS}

\section{Plant material preparation and extraction}

Lemongrass (Cymbopogon citratus) plant used in the study were collected from Ngantang Subdistrict, Malang District, East Java, Indonesia; its geographical coordinates are $7^{\circ} 51$ ' 0 "S, $112^{\circ} 22^{\prime} 0^{\prime \prime}$ E. Lemongrass was harvested at 6 months of age. Lemongrass after harvesting was separated between its stalks and leaves and cut into small pieces at the length of 4 to $8 \mathrm{~mm}$ then was distilled in fresh form. Distillation of lemongrass leaves and lemongrass stalk were done by steam-hydrodistillation or steamed system. This method is also called indirect distillation because the raw material is not directly related to boiling water, but is related to water vapor. The working principle of this distillation is as follows: the distillation kettle is filled with water up to a limit of $5 \mathrm{~cm}$ below the filter. The raw material is placed on the filter. Evaporated water will carry the essential oil particles and flow through a pipe to the cooler so that condensation occurs and the water vapor mixed with the essential oil will melt again. Then flowed into a separator to separate essential oils from water. Distillation was carried out by essential oil distillation machine with a capacity of $5 \mathrm{~kg}$ for $4 \mathrm{~h}$ with the temperature maintained at approximately $100^{\circ} \mathrm{C}$. Lemongrass stalk essential oils (LSEO) and lemongrass leaves essential oil (LLEO) produced were kept in a sealed glass bottle at room temperature and away from direct sunlight exposure.

\section{Gas chromatography-mass spectrometry analysis}

The GC-MS analysis of LSEO and LLEO were performed using GCMS-QP2010 Ultra System (Shimadzu, Japan), equipped with a DB-5 MS capillary column (30 m× $0.25 \mathrm{~mm}$ i.d. and $0.25 \mu \mathrm{m}$ film thickness; Agilent Technologies, J \& W Scientific, CA, U.S.A.), crosslinked 5\% Phenyl-methylpolysiloxane. GC-MS was detected using an electron ionization system with $70 \mathrm{eV}$ ionization energy and analysis was measured in scan mode with the mass spectra scan range of $20-800 \mathrm{~m} / \mathrm{z}$. The carrier gas was helium ultrapure and was used with a constant flow rate of $0.70 \mathrm{~mL} / \mathrm{min}$. The oven temperature for separation was initially set to $40{ }^{\circ} \mathrm{C}$, then increased to $250^{\circ} \mathrm{C}$ at the rate of $5^{\circ} \mathrm{C} / \mathrm{min}$, and held at $250^{\circ} \mathrm{C}$ for $10 \mathrm{~min}$. The injector temperature was set to $250^{\circ} \mathrm{C}$ and injection volume was 1 $\mu \mathrm{L}$ with the split ratio of 100: 1 .
Identification of components of LEO oil was assigned by comparing the relative retention indexes of GC peaks with the indexes generated by fusing saturated $n$-alkanes (C8-C23, ally Science Inc., Niles, USA) and by comparing of the mass spectra of the peaks with the mass spectra reported and stored in National Institute of Standards and Technology (NIST) and Wiley (Flavour \& Fragrance Natural \& Synthetic Compounds, FFNSC 1.2lib) (Yen and Lin 2017).

\section{RESULTS AND DISCUSSION}

Ngantang has hilly and terrain topography. The fertile soil conditions make Ngantang as one of the regions producing various agricultural crops. However, lemongrass plants are also widely found in Ngantang but are not cultivated intensively. Lemongrass plants are generally planted in the yard of the house as a spice plant. This plant is used as a spice in cooking and it used only part of the stalk only while the leaves are just thrown away as waste. Actually, Lemongrass might be extracted to obtain essential oils useful for various application such as perfumery, cosmetics, flavor and fragrance ingredients, food preservative, pharmaceutical and medicinal application (Desai et al. 2013). Lemongrass essential oil is regarded as one of the most important essential oils being produced and regarded as safe (Abdulazeez et al. 2016). Lemongrass contains several bioactive compounds, due to it has broad bioactivity such as antibacterial activity, antioxidant activity, antifungal activity, antidiabetic activity, antigout activity (Mirghani et al. 2012; Balakrishman et al. 2014; Ekpenyong et al. 2015; Liakos et al. 2016). The bioactivity of lemongrass essential oil is attributed to its physiochemical constituents. The chemical composition of lemongrass essential oil varies by geographic region, genetic differences, the part of plant used for extraction, the method of extraction, the age/stage of maturity, the season of harvest, and even the health status of the plant (Shah et al. 2011; Bharti et al. 2013; Ekpenyong et al. 2014a; Ekpenyong et al. 2014b). In this study, the Bioactive compounds of Lemongrass essential oil were obtained from stalk (LSEO) are displayed in Figure 1 and Table 1 . while the bioactive compounds of essential oils produced from leaves (LLEO) are displayed in Figure 2 and Table 2.

The result showed that the lemongrass essential oil produced by hydrodistillation and analyzed by GC-MS contains the main bioactive compounds namely neral (ciscitral) and geranial (trans-citral). GC-MS analysis revealed that the content of bioactive compounds in LSEO and LLEO was citral (geranial and neral) of $91.67 \%$ and $45.75 \%$. This means that the quality of LSEO is higher than LLEO. this is because the components that made up LLEO are more than LSEO. LLEO contains 6-Methyl-5 heptane2 -one of $14,137 \%$, beta myrcene $18,771 \%$, trans-geraniol $10,689 \%$. while SLEO only contains trans-geraniol $1.832 \%$ The low citral content in LLEO may be caused by the proportion of young leaves more than the old leaves. 


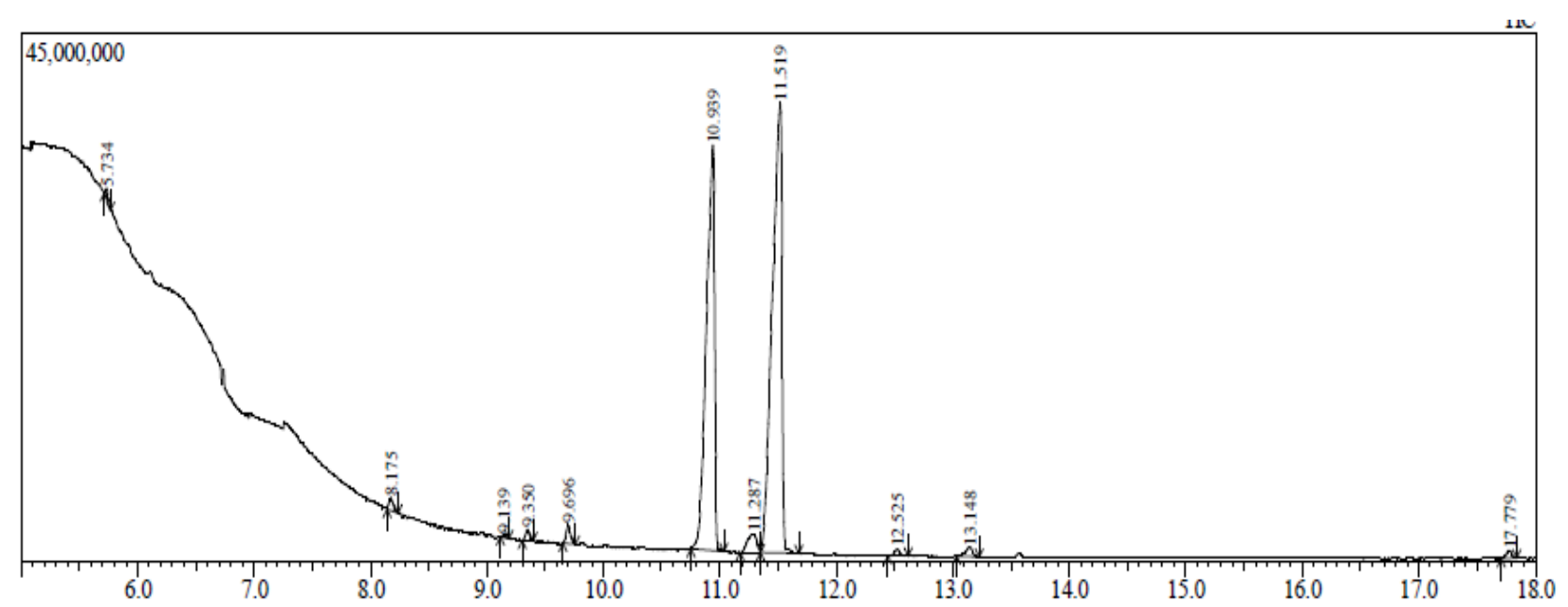

Figure 1. Chromatogram of SLEO

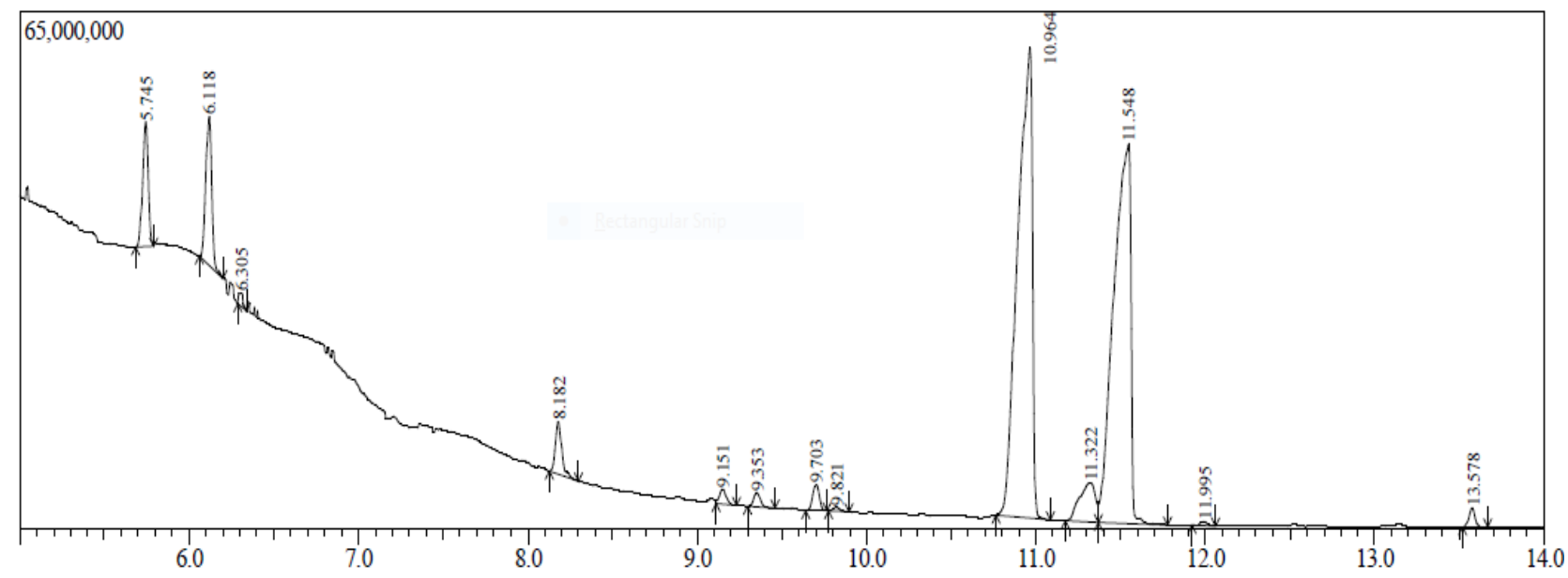

Figure 2. Chromatogram of LLEO

Table 1. Chemical composition of LSEO

\begin{tabular}{lll}
\hline \multicolumn{1}{c}{$\begin{array}{c}\text { Bioactive } \\
\text { compound }\end{array}$} & $\begin{array}{c}\text { Retention } \\
\text { time }\end{array}$ & $\begin{array}{c}\text { Conc. } \\
(\mathbf{\%})\end{array}$ \\
\hline 6-Methyl-5-heptane-2-one & & \\
Linalool & - & - \\
Citronellal & 8.167 & 0.930 \\
Limonene oxide & 9.147 & 0.110 \\
3-Undecyne & - & - \\
Neral & 9.700 & 0.585 \\
trans-Geraniol & 10.939 & 36.501 \\
Geranial & 11.287 & 1.832 \\
1,6-Octadiene, 2,6-dimethyl & 11.518 & 55.172 \\
1-Oxacyclopropyl-3,4-epoxy cyclohexane & 12.521 & 0.242 \\
Juniper camphor & 13.144 & 0.513 \\
1,2-Benzenedicarboxylic acid & 17.778 & 0.166 \\
& 21.989 & 3.948 \\
\hline
\end{tabular}

Table 2. Chemical composition of LLEO

\begin{tabular}{lcc}
\hline \multicolumn{1}{c}{$\begin{array}{c}\text { Bioactive } \\
\text { compound }\end{array}$} & $\begin{array}{c}\text { Retention } \\
\text { time }\end{array}$ & $\begin{array}{c}\text { Conc. } \\
(\boldsymbol{\%})\end{array}$ \\
\hline 6-Methyl-5-heptane-2-one & & \\
beta.-Myrcene & 5.745 & 14.137 \\
Linalool & 6.118 & 18.771 \\
Citronellal & 8.182 & 3.351 \\
Limonene oxide & 9.151 & 1.302 \\
Longipinenepoxide & 9.354 & 0.811 \\
cis-Carveol & 9.704 & 1.759 \\
Neral & 9.821 & 0.249 \\
trans-Geraniol & 10.965 & 19.225 \\
Geranial & 11.323 & 10.686 \\
2-Undecanone (CAS) 2-Hendecanone & 11.555 & 26.522 \\
Geranyl acetate & 11.993 & 0.467 \\
trans-Caryophyllene & 13.577 & 1.359 \\
delta.-Guaiene & 14.981 & 0.130 \\
Patchouli alcohol & 16.079 & 0.171 \\
& 18.507 & 1.060 \\
\hline
\end{tabular}


The higher quality products with high citral content are affected by the proportion of young leaves and old leaves when harvested. Generally, the essential oil yield is highly correlated with biomass yield (Tajidin et al. 2012). A study by Mirghani et al. was shown the lemongrass stalk essential oil consisted of 68 compounds while lemongrass leaves essentials oil consisted of 72 compounds (Mirghani et al. 2012). The results of this study are different from those conducted at Bali (Putra et al. 2012) which showed that the citral content of essential oils made from leaves (Plaga 70.68\% and Tabanan $79.73 \%$ ) higher than made from stalk (Plaga 63.29\% and Tabanan 76.93\%0) this difference is caused by differences in the area and the method of distillation. Other researchers report that the citral content in essential oils from lemongrass stalk and lemongrass leaves in Malaysia by distilled water was $54.46 \%$ and $51.13 \%$ (Mirghani et al. 2012). In addition, essential oils are obtained from the leaves and stem of Cymbopogon citratus in Brazil obtained by hydrodistillation and GC-MS analyzed has been reported (Andrade et al. 2009).

The content of lemongrass oil cultivated in northern Brazil varies greatly according to section plant. the highest oil yield was obtained from rhizomes $(2.7 \%)$, followed by leaves $(1.9 \%)$ and stalk $(0.9 \%)$. The composition is found for each different part of the plant revealed that leaves and stalk showed the same chemical profile, with high numbers of neral and geranial (leaves: $30.1 \%$ and $39.9 \%$ respectively or citral $70.0 \%$; stalk: $27.8 \%$ and $50.0 \%$ respectively or citral $77.8 \%)$, compared to rhizomes $(5.0 \%$ and $9.6 \%$. respectively or citral $14.6 \%$ ). The main compound identified in rhizome oil is selina-6-en-4-ol $(27.8 \%)$. The oil from the leaves besides being rich in citral, it is also rich in $17.8 \%$ myrcene content. This variety of citral contents found in Cymbopogon citratus essential oils due to the genetic diversity, area of growth, culture, and agronomic treatment (Haque et al. 2018). The content of citral or 3,7-dimethyl-2,6-octadienal in lemongrass essential oil is very much to be discussed because the quality of this product is generally determined by the amount of citral. Citral is used in the production of vitamin A and ionone (Kumar et al. 2015; Ajayi et al. 2016). In addition, besides citral, lemongrass essential oil consists of other bioactive compounds were limonene, citronella betamyrcene, geraniol, and others.

Minor components in lemongrass essential oil are also important for antimicrobial activity because of their synergistic effects. this is based on several studies that have concluded that all whole essential oils exhibit greater antibacterial activity than the main component (Jiang et al. 2011; Layse et al. 2012). In addition, the content of citral harvested at 6.5 months is $11.4 \%$ higher than that harvested at 5.5 months. Citral content decreases by $5.4 \%$ when lemongrass is harvested at 6.5 months compared to when harvested at 7.5 months. Citral content peaked at the age of $6.7 \pm 0.3$ months. Thus, the level of maturity at harvest significantly affects essential oils and citral content. Therefore, lemongrass must be harvested at the right level of maturity to achieve high-quality essential oils and lower production costs (Tajidin et al. 2012). The effect of the drying method on the yield and composition of essential oils from lemongrass extracted by hydrodistillation has been reported by (Kumar et al. 2015). This method of sun drying gives the best results from essential oils followed by oven drying hot air carried out at $60^{\circ} \mathrm{C}$ and microwaves. the composition of fresh wet lemongrass essential oil was citral a $36.21 \%$ and citral b $26.21 \%$. Citral a content decreases about $2 \%$ and citral b content increases about $1.5 \%$ in a different drying method compared with fresh leaves lemongrass essential oil may be due to the conversion of citral isomer a (geranial) to citral isomer b (neral) during the drying process. Other researchers were evaluated essential oil productivity and chemical compositions of the eight lemongrass cultivars from the Himalayan region. Their results showed variations in the essential oil compositions due to cultivars and season of harvest. The citral contents were varied from $70.8 \%$ to $91.6 \%$ in different cultivars during the summer, rainy, and winter seasons. based on the essential oils yield, Krishna cultivars (2.35 L per $100 \mathrm{~m}^{2}, 70.8-86.8 \%$ citral content with an average of $80 \%$ ) was superior to other cultivars namely Nima (88.8-91.6\%), Pragati (84.1-91.2\%), Cauvery (83.987.3\%), Krishna-70 (82.0-86.0\%), Chirharit (78.6-82.8\%), Praman (75.2-82.5\%), CKP-25 (77.6-79.4\%) (Verma et al. 2015).

In conclusion, bioactive compounds in essential oil from lemongrass cultivated in Ngantang, Malang, East Java, Indonesia was indicated differences between parts of the plant. LSEO contains 11 of bioactive compounds while LLEO contains 15 of bioactive compounds. Lemongrass in Ngantang was included the citral chemotype. The main compound namely citral. The citral content of LSEO is higher than the citral content of LLEO but LLEO also contains a fairly high amount of myrcene and transgeraniol. Therefore to increase the content of citral in LLEO, there needs to be an improvement in cultivation treatment and age of harvesting.

\section{ACKNOWLEDGEMENTS}

This work was supported by the Directorate of Research and Community Service, Indonesian Ministry of Research, Technology and Higher Education, and the University of Muhammadiyah Malang, Indonesia. The authors wish to thank for the funding of Doctoral Dissertation Research.

\section{REFERENCES}

Abdulazeez MA, Abdullahi AS, James BD. 2016. Lemongrass (Cymbopogon spp.) oils. In: Preedy, V. (Ed.), Essential Oils in Food Preservation, Flavor, and Safety. Academic Press, London.

Ajayi EO, Sadimenko AP, Afolayan AJ. 2016. GC-MS evaluation of Cymbopogon citratus (DC) Stapf oil obtained using modified hydrodistillation and microwave extraction methods. Food Chemistry, 209: 262-266. DOI: 10.1016/j.foodchem.2016.04.071

Andrade EHA, Zoghbi M, das GB., Lima, M. da P., 2009. Chemical composition of the essential oils of Cymbopogon citratus (DC.) Stapf cultivated in north of brazil. J Essent Oil Bearing Plants 12 (1): 41-45. 
Avoseh O, Oyedeji O, Rungqu P, et al. 2015. Cymbopogon species: Ethnopharmacology, phytochemistry and pharmacological importance. Molecules 20: 7438-7453.

Balakrishnan B, Paramasivana S, Arulkumar A. 2014. Evaluation of the lemongrass plant (Cymbopogon citratus) extracted in different solvents for antioxidant and antibacterial activity against human pathogens. Asian Pac J Trop Dis 4 (Suppl 1): S134-S139

Bharti SK, Kumar A, Prakash O, et al. 2013. Essential oil of Cymbopogon citratus against diabetes: Validation by In vivo experiments and computational studies. J Bioanal Biomed 5 (5): 194-203.

Desai, M.A., Parikh, J., De, A.K., 2013. Modelling and optimization studies on extraction of lemongrass oil from Cymbopogon flexuosus (Steud.) Wats. Chem Eng Res Design 92 (5): 793-803. DOI: 10.1016/j.cherd.2013.08.011.

Ekpenyong C, Daniel N, Akpan E. 2014. Phytoconstituents and diuretic activity of Cymbopogon citratus leaf infusions in humans. J Coastal Life Med 2 (9): 704-713.

Ekpenyong CE, Akpan E, Nyoh A. 2015. Ethnopharmacology, phytochemistry, and biological activities of Cymbopogon citratus (DC .) Stapf extracts. Chinese J Natural Medicines, 13 (5): 321-337. DOI: $10.1016 / \mathrm{S} 1875-5364$ (15)30023-6.

Ekpenyong CE, Akpan EE, Daniel NE. 2014. Phytochemical Constituents, Therapeutic Applications and Toxicological Profile of Cymbopogon citratus Stapf (DC) Leaf Extract. J Pharmacogn Phytochem 3 (1): 133-141

Haque ANMA, Remadevi R, Naebe M. 2018. Lemongrass (Cymbopogon): a review on its structure, properties, applications and recent developments. Cellulose. DOI: 10.1007/s10570-018-1965-2

Jiang Y, Wua N, Fua Y, et al. 2011. Chemical composition and antimicrobial activity of the essential oil of Rosemary. J Etap 32 (1) 63-68. DOI: 10.1016/j.etap.2011.03.011

Kumar V, Tewaria R, Singh K. 2015. Comparative studies of drying methods on yield and composition of the essential oil of Cymbopogon citratus. J Essent Oil Bearing Plants 18 (3): 744-750. DOI: 10.1080/0972060X.2014.935069.
Layse S, Sarrazin SLF, Oliveira RB, et al. 2012. Chemical composition and antimicrobial activity of the essential oil of Lippia grandis Schauer (Verbenaceae) from the western Amazon. Food Chem 134 (3): 1474-1478. DOI: 10.1016/j.foodchem.2012.03.058.

Liakos IL, D'autilia F, Garzoni A, et al. 2016. All natural cellulose acetate-lemongrass essential oil antimicrobial nanocapsules. Intl $\mathbf{J}$ Pharm 510 (2): 508-515.. DOI: 10.1016/j.ijpharm.2016.01.060

Mirghani MES, Liyana Y, Parveen J. 2012. Bioactivity analysis of lemongrass (Cymbopogon citratus) essential oil. Intl Food Research Journal, 19 (2): 569-575.

Putra INK, Antara NS, Wartini IM. 2012. Bioactive components of leaf and stalk of lemongrass (Cymbopogon citratus) essential oil and its antioxidant activity. International Conference: Future of Food Factors. Udayana University, Denpasar, Bali

Shah G, Shri R, Panchal V, et al. 2011. Scientific basis for the therapeutic use of Cymbopogon citratus, Stapf (Lemon grass). J Adv Pharmaceut Technol Res 2 (1): 3-8.

Sidibé L, Chalchat JC, Garry RP, et al. 2011. Aromatic plants of Mali (IV): Chemical composition of essential oils of Cymbopogon citratus (DC) Stapf and C. giganteus (Hochst.) Chiov. J Essential Oil Res, 13 (2): 110-112.

Soares MO, Vinha AV, Barreira SVP, et al. 2013. Cymbopogon citratus EO antimicrobial activity against multi-drug resistant Gram-positive strains and non-albicans-Candida species. In: Méndez-Vilas A (ed.). Microbial Pathogens and Strategies for Combating them: Science, Technology and Education. Formatex Research Center, Spain.

Tajidin NE, Ahmad SH, Rosenani AB, et al. 2012. Chemical composition and citral content in lemongrass (Cymbopogon citratus) essential oil at three maturity stages. Afr J Biotechnol 11 (11): 2685-2693.

Verma RK, Verma RS, Chauhan A, Bisht A. 2015, Evaluation of essential oil yield and chemical composition of eight lemongrasses (Cymbopogon spp .) cultivars under Himalayan region. J Essent Oil Res 27 (3): 197-203.

Yen HY, Lin YC. 2017. Green extraction of Cymbopogon citrus essential oil by solar energy. Industr Crops Prod 108: 716-721. 